\title{
Synthesis of both enantiomer of akolactone B and (+)-ancepsenolide
}

\author{
Gen Hikosaka, ${ }^{\mathrm{a}}$ Yasunao Hattori, ${ }^{\mathrm{b}}$ Hidefumi Makabe*a
}

${ }^{a}$ Sciences of Functional Foods, Graduate School of Agriculture, Shinshu University, 8304 Minami-minowa, Kamiina, Nagano 399-4598, Japan

${ }^{\mathrm{b}}$ Department of Medicinal Chemistry, Kyoto Pharmaceutical University, Yamashina-ku, Kyoto 607-8412, Japan

*Corresponding author. Tel. +81 26577 1630; fax +81 26577 1700, e-mail: makabeh@shinshu-u.ac.jp

\begin{abstract}
The syntheses of (+)- and (-)-akolactone B and (+)-ancepsenolide was accomplished using Pdcatalyzed carbonylation. As to the absolute configuration of akolactone B, making a comparison of the optical rotation of both enantiomers of synthetic akolactone B and the natural compound suggests that the absolute configuration at the 4-position of akolactone $\mathrm{B}$ is $R$.
\end{abstract}

Key words: lactones, stereoselective synthesis, natural product, absolute configuration, carbonylation

\section{Introduction}

The substructures of $\alpha, \beta$-unsaturated butanolide are seen in bioactive natural products such as annonaceous acetogenins. ${ }^{1}$ Akolactone B (1), an $\alpha, \beta$-unsaturated butanolide derivative, has shown cytotoxicity toward human tumorial cell lines, has been isolated by Chen and co-workers from the stem bark of Litsea akoensis in $1998 .^{2}$ The isolated material was determined to be $\alpha, \beta$-unsaturated- $\gamma$-lactone, connected with a trans-olefinic group at the C-2 position and conjugated trans-diene at terminal one. However, its stereochemistry at the C-4 chiral center has not been determined yet. Synthesis of $\mathbf{1}$ has not been reported either. (+)-Ancepsenolide (2) was isolated from Pterogorgia anceps ${ }^{3}$ P. citrina,${ }^{4}$ and P. guadalupensis,${ }^{5}$ respectively. Several syntheses of (+)ancepsenolide (2) have been reported. ${ }^{6}$ Iriye and co-worker reported the synthesis of 2 using $(S)-(-)-2-[(R)-O-$ MEM-mandeloyloxy]propanal. ${ }^{6 a}$ In this synthesis, the yield of each transformation was not good. Recently Baati and co-workers reported the synthesis of 2 using a-substituted butenolide as a key intermediate. ${ }^{6 \mathrm{~b}}$ This synthesis suffered from the low yield of palladium-catalyzed reduction of enol triflate. In the previous report, we described the synthesis of both enantiomers of akolactone A and the determination of its absolute configuration at C-4 
position. $^{7}$ Herein we wish to report the total synthesis of both enantiomer of akolactone B (1) and (+)ancepsenolide (2) using Pd-catalyzed carbonylation and spontaneous lactonization. We also wish to describe determination of the absolute configuration of natural akolactone B (Figure 1).

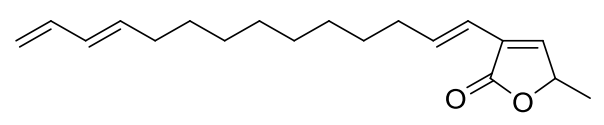

akolactone B (1)

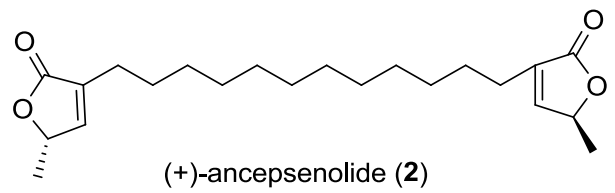

(+)-ancepsenolide (2)

Figure 1. The structures of akolactone B (1) and (+)-ancepsenolide (2).

\section{Results and Discussion}

The synthetic method used for both enantiomers of akolactone B is shown in Scheme 1. We chose 1,9nonanediol (3) as a starting material. 9-tert-Butylsilyloxynonan-1-ol (4) was prepared by protecting one of the hydroxy groups of 1,9-nonanediol (3) with tert-butyldimethylsilyl chloride in the presence of imidazole. ${ }^{8}$ Transformation of compound $\mathbf{4}$ to $\mathbf{7}$ was performed as described below according to the procedure reported by Hegedus and co-workers except that hydrozirconated product was treated with iodine instead of NIS which is rather expensive reagent. ${ }^{9}$ Mesylation followed by iodination of hydroxy group of $\mathbf{3}$ using NaI in the presence of sodium bicarbonate gave iodide 5. ${ }^{10}$ Alkynylation of $\mathbf{5}$ with lithium acetylide ethylenediamine complex furnished terminal alkyne 6. Hydrozirconation using Schwarz reagent followed by treatment with iodine afforded vinyl iodide $7 .{ }^{11}$ Deprotection of the TBS group of $\mathbf{7}$ with TBAF afforded primary alcohol $\mathbf{8}$. Alcohol $\mathbf{8}$ was also synthesized by Suginome and co-workers using 11-hydroxy-1-uncenyl boronic acid as a key intermediate. ${ }^{12}$ The yield of this synthesis ( $38 \%$ in 5 steps) was little bit higher than ours (34\% in 5 steps), however, the experimental procedure of our synthesis was simpler than that of the reported synthesis. Oxidation of the primary alcohol $\mathbf{8}$ with $\mathrm{SO}_{3} \cdot$ pyridine and DMSO afforded aldehyde 9. Horner-Wadsworth-Emmons reaction using diethyl allylphosphonate gave 10. The Sonogashira cross-coupling reaction of $\mathbf{1 0}$ with $(R)-(+)-3$-butyn-2-ol using pyrrolidine as a base furnished 11. ${ }^{13}$ Regioselective hydroalumination of $\mathbf{1 1}$ with sodium bis(2methoxyethoxy)aluminum hydride (Red-Al $\left.{ }^{\circledR}\right)$ and successive treatment with EtOAc and iodine gave vinyl iodide 12. Pd-catalyzed carbonylation and spontaneous lactonization of $\mathbf{1 2}$ with 1 atmosphere of $\mathrm{CO}$ in the presence of $5 \mathrm{~mol} \%$ of $\mathrm{Cl}_{2} \mathrm{Pd}\left(\mathrm{PPh}_{3}\right)_{2}, \mathrm{~K}_{2} \mathrm{CO}_{3}$ and $\mathrm{Et}_{3} \mathrm{~N}$ in the presence of hydrazine at $40{ }^{\circ} \mathrm{C}$ afforded $(R)-(-)$-akolactone $\mathrm{B}$ (1a) in a $63 \%$ yield. ${ }^{14}$ The ${ }^{1} \mathrm{H}$ - and ${ }^{13} \mathrm{C}-\mathrm{NMR}$, and IR spectra of synthetic 1a were in good agreement with the reported values. ${ }^{2}$ The optical rotation of synthetic $\mathbf{1 a}\left([\alpha]^{18} \mathrm{D}=-38.1, c 1.10, \mathrm{CHCl}_{3}\right)$ is larger than those of the reported value for naturally occurring akolactone $\mathrm{B}\left\{[\alpha]^{27} \mathrm{D}=-10.0,\left(c 0.10, \mathrm{CHCl}_{3}\right)\right\}$. Taking into account that optical rotation of natural product was measured in low concentration, the difference may be due to experimental error or contamination of impurity (Scheme 1). ${ }^{2}$ We also synthesized $(S)-(+)$-akolactone B (1b) using $(S)-(-)-3-$ 
butyn-2-ol (Scheme 2). The optical rotation of $\mathbf{1 b}$ was $+35.8\left(c 0.500, \mathrm{CHCl}_{3}\right)$. On the basis of these results, we assigned the absolute configuration of natural akolactone $\mathrm{B}$ at the $\mathrm{C}-4$ position to be $R$.

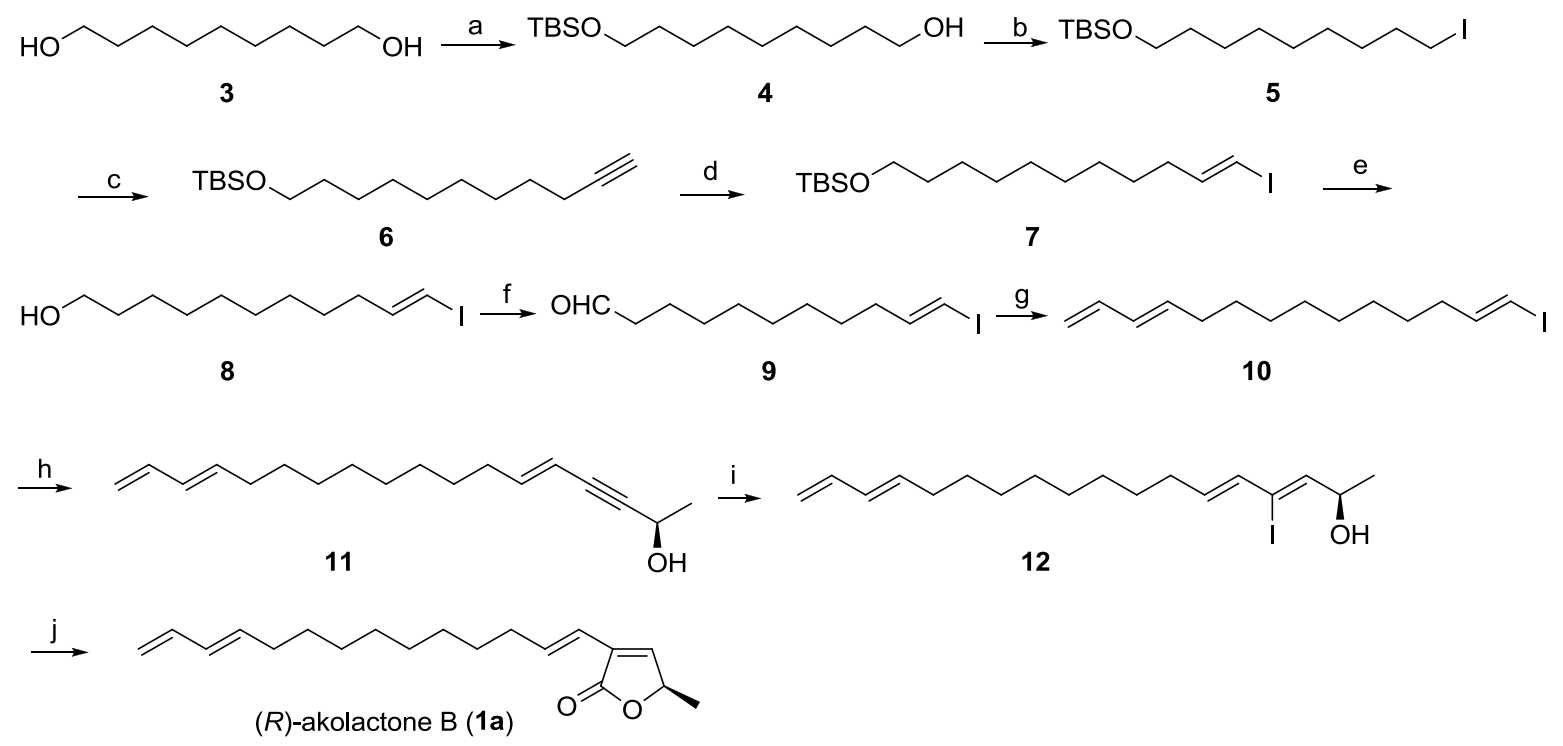

Scheme 1. Synthesis of $(R)$-akolactone B (1a).

Regents and conditions: (a) TBSCl, imidazole, $\mathrm{CH}_{2} \mathrm{Cl}_{2}, 58 \%$; (b) (i) $\mathrm{MsCl}, \mathrm{Et}{ }_{3} \mathrm{~N}, \mathrm{CH}_{2} \mathrm{Cl}_{2}, 0$ ' $\mathrm{C}$; (ii) $\mathrm{NaI}, \mathrm{NaHCO}_{3}$, acetone, 93\%; (c) lithium acetylide ethylenediamine complex, DMSO, 83\%; (d) $\mathrm{Cp}_{2} \mathrm{ZrHCl}$, THF, 81\%; (e) TBAF, THF, 94\%; (f) $\mathrm{SO}_{3}$ pyridine, DMSO, 84\%; (g) diethyl allylphosphonate, $n$-BuLi, THF-HMPA, 46\%; (h) (R)-3-bytyn-2-ol, $\mathrm{Cl}_{2} \mathrm{Pd}\left(\mathrm{PPh}_{3}\right)_{2}$, CuI, pyrrolidine, 79\%; (i) (i) Red-Al ${ }^{\circledR}$, THF; (ii) EtOAc, (iii) $\mathrm{I}_{2}, \mathrm{THF}, 75 \%$; (j) $\mathrm{Cl}_{2} \mathrm{Pd}\left(\mathrm{PPh}_{3}\right)_{2}, \mathrm{CO}, \mathrm{K}_{2} \mathrm{CO}_{3}, \mathrm{Et}_{3} \mathrm{~N}, \mathrm{NH}_{2} \mathrm{NH}_{2}, \mathrm{THF}, 40{ }^{\circ} \mathrm{C}, 63 \%$.

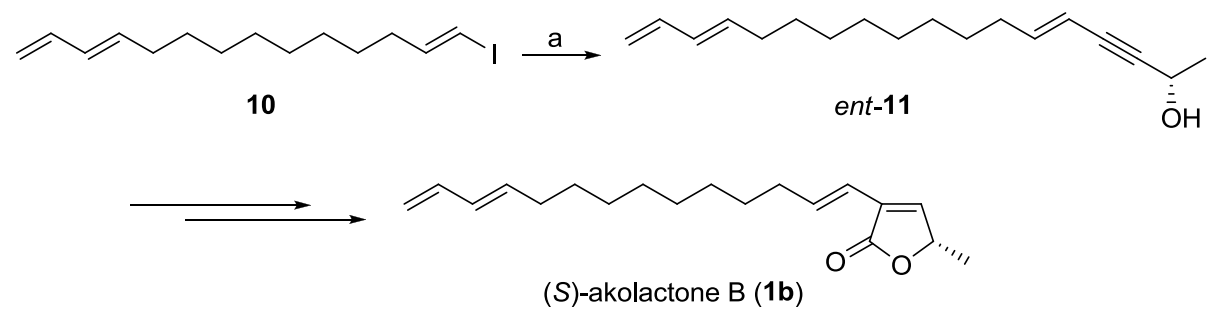

Scheme 2. Synthesis of (S)-akolactone B (1b).

Regents and conditions: (a) (S)-3-bytyn-2-ol, $\mathrm{Cl}_{2} \mathrm{Pd}\left(\mathrm{PPh}_{3}\right)_{2}$, $\mathrm{CuI}$, pyrrolidine, $86 \%$

As to the synthesis of (+)-ancepsenolide, we selected 1,12-dodecanediol (13) as a starting material. Mesylation followed by iodination of both of the hydroxy groups of 13 using NaI gave diiodide 14. Diiodide 14 was also prepared by Ainscow and co-workers from cyclododecanone through 5 steps. ${ }^{15}$ Our synthetic procedure was much more efficient than that of the reported. Alkynylation of 14 with TBS protected (S)-(-)-3-butyn-2-ol afforded alkyne 15. Removal of the TBS group of $\mathbf{1 5}$ with TBAF followed by regioselective hydroalumination using Red-Al ${ }^{\circledR}$ and successive treatment with EtOAc and iodine gave vinyl iodide 17. Pd-catalyzed carbonylation and spontaneous lactonization of 17 with 1 atmosphere of $\mathrm{CO}$ in the presence of $5 \mathrm{~mol} \%$ of $\left.\mathrm{Cl}_{2} \mathrm{Pd}_{(} \mathrm{PPh}_{3}\right)_{2}, \mathrm{~K}_{2} \mathrm{CO}_{3}$ 
and $\mathrm{Et}_{3} \mathrm{~N}$ in the presence of hydrazine at $40{ }^{\circ} \mathrm{C}$ afforded (+)-ancepsenolide (2) in $79 \%$ yield. ${ }^{14}$ The ${ }^{1} \mathrm{H}-$ and ${ }^{13} \mathrm{C}$ NMR, IR spectra and physicochemical data of synthetic 2 were in good agreement with those of the reported values (Scheme 3$)^{6}$

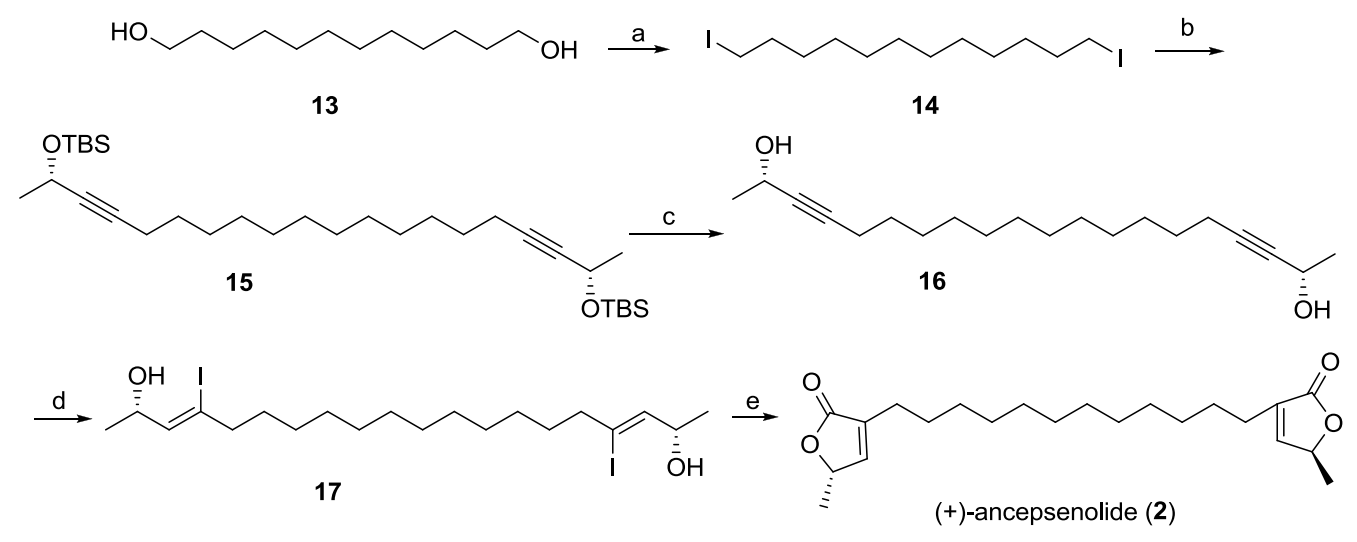

Scheme 3. Synthesis of (+)-ancepsenolide (2).

Regents and conditions: (a) (i) $\mathrm{MsCl}, \mathrm{Et}_{3} \mathrm{~N}, \mathrm{CH}_{2} \mathrm{Cl}_{2}, 0{ }^{\circ} \mathrm{C}$;; (ii) NaI, acetone, 84\%; (b) (S)-3-(tertbutuldimethylsilyloxy)but-1-yn, $n$-BuLi, THF-HMPA, 94\%; (c) TBAF, THF, 61\%; (d) (i) Red-Al®, THF; (ii) EtOAc, (iii) $\mathrm{I}_{2}$, THF, 86\%; (e) $\mathrm{Cl}_{2} \mathrm{Pd}\left(\mathrm{PPh}_{3}\right)_{2}, \mathrm{CO}, \mathrm{K}_{2} \mathrm{CO}_{3}, \mathrm{Et}_{3} \mathrm{~N}, \mathrm{NH}_{2} \mathrm{NH}_{2}, \mathrm{THF}, 40{ }^{\circ} \mathrm{C} 79 \%$.

\section{Conclusion}

In conclusion, we accomplished the syntheses of both enantiomer of akolactone B and (+)-ancepsenolide using Pd-catalyzed carbonylation and lactonization. A comparison of the optical rotation of both enantiomers of akolactone $\mathrm{B}$ and the natural compound suggests that the absolute configuration at the 4-position of akolactone $\mathrm{B}$ is $R$.

\section{Experimental}

4.1. General. All melting points were uncorrected. ${ }^{1} \mathrm{H}$ and ${ }^{13} \mathrm{C}$ NMR spectra were measured with a Bruker DRX 500 FT-NMR spectrometer in $\mathrm{CDCl}_{3}$ at 500 and $125 \mathrm{MHz}$, respectively. Chemical shifts were relative to tetramethylsilane as an internal standard. The coupling constants were given in Hz. Mass spectra were obtained on JEOL JMS-HX211A and JMS-HX110A mass spectrometer. IR spectra were recorded with JASCO FT-IR 480 Plus infrared spectrometer. Optical rotations were determined with a JASCO DIP-1000 polarimeter.

4.1.1. 9-tert-Butyldimethylsilyloxynonan-1-ol (4). To a solution of 1,9-nonanediol (0.50 g, $3.12 \mathrm{mmol})$ in $\mathrm{CH}_{2} \mathrm{Cl}_{2}(15 \mathrm{~mL})$ were added imidazole $(212 \mathrm{mg}, 3.12 \mathrm{mmol})$ and $\mathrm{TBSCl}(470 \mathrm{mg}, 3.12 \mathrm{mmol})$. After the reaction 
had been stirred for $30 \mathrm{~min}$, the reaction was quenched with water and the mixture was extracted with ethyl acetate. The organic layer was successively washed with water and brine, dried over $\mathrm{MgSO}_{4}$, and concentrated. The crude product was purified by silica gel column chromatography (hexane:AcOEt = 5:1) to give 4 (1.00 g, $58 \%$ ) as a colorless oil. The spectral data of $\mathbf{4}$ were identical with those of the reported values. ${ }^{8}$

4.1.2. 9-(tert-Butyldimethylsilyloxy)-1-iodononane (5). To a solution of 4 (4.68 g, $17.1 \mathrm{mmol})$ and $\mathrm{Et}_{3} \mathrm{~N}(4.75$ $\mathrm{mL}, 34.1 \mathrm{mmol})$ in $\mathrm{CH}_{2} \mathrm{Cl}_{2}(35 \mathrm{~mL})$ was added $\mathrm{MsCl}(1.72 \mathrm{~mL}, 22.2 \mathrm{mmol})$ at $0{ }^{\circ} \mathrm{C}$. The reaction mixture was stirred for $30 \mathrm{~min}$ at this temperature. After the reaction had been completed, the mixture was extracted with ether. The organic solution was successively washed with saturated aqueous $\mathrm{NH}_{4} \mathrm{Cl}$, water, and brine, dried over $\mathrm{MgSO}_{4}$, and concentrated. The crude product was dissolved in acetone $(20 \mathrm{~mL})$ and $\mathrm{NaI}(4.30 \mathrm{~g}, 51.3 \mathrm{mmol})$ and $\mathrm{NaHCO}_{3}(4.30 \mathrm{~g}, 51.3 \mathrm{mmol})$ was added to this solution. After being stirred for $16 \mathrm{~h}$, the reaction was quenched with water. The organic materials were extracted with ether and organic layer was successively washed with water and brine, dried over $\mathrm{MgSO}_{4}$, and concentrated. The crude product was purified by silica gel column chromatography (hexane:AcOEt $=20: 1)$ to give $5(6.14 \mathrm{~g}, 93 \%)$ as a pale yellow oil. The spectral data of 5 were identical with those of the reported values. ${ }^{10}$

4.1.3. 11-(tert-Butyldimethylsilyloxy)undec-1-yne (6). To a suspension of lithium acetylide ethylenediamine complex (1.12 g, $10.9 \mathrm{mmol})$ in DMSO $(18 \mathrm{~mL})$ was added $5(3.50 \mathrm{~g}, 9.10 \mathrm{mmol})$ at $0^{\circ} \mathrm{C}$. After stirring for $1 \mathrm{~h}$, the mixture was diluted with ether and the reaction was quenched with saturated aqueous $\mathrm{NH}_{4} \mathrm{Cl}$. The organic layer was successively washed with water and brine, dried over $\mathrm{MgSO}_{4}$, and concentrated. The crude product was purified by silica gel column chromatography (hexane:AcOEt $=20: 1)$ to give $6(2.13 \mathrm{~g}, 83 \%)$ as a colorless oil. The spectral data of $\mathbf{6}$ were identical with those of the reported values. ${ }^{9}$

4.1.4. (E)-11-(tert-Butyldimethylsilyloxy)-1-iodoundec-1-ene (7). To a solution of 6 (3.10 g, $11.1 \mathrm{mmol})$ in THF (55 mL) was added $\mathrm{Cp}_{2} \mathrm{ZrHCl}(3.60 \mathrm{~g}, 13.3 \mathrm{mmol})$. After stirring for 3h, $\mathrm{I}_{2}$ (5.60 g, $\left.22 \mathrm{mmol}\right)$ in THF (10 $\mathrm{mL}$ ) was added to the mixture at $0^{\circ} \mathrm{C}$ and the resulting mixture was stirred for $30 \mathrm{~min}$ at room temperature. The reaction was quenched with saturated aqueous $\mathrm{Na}_{2} \mathrm{~S}_{2} \mathrm{O}_{3}$ and the mixture was filtered through Celite and the solvent was concentrated. The residue was purified with silica gel column chromatography (hexane:AcOEt $=$ 20:1) to afford $7(3.70 \mathrm{~g}, 81 \%)$ along with $8(14 \%)$. The spectral data of 7 were identical with those of the reported values. ${ }^{9}$ 
4.1.5. (E)-11-Iodoundec-10-en-1-ol (8). To a solution of $7(581 \mathrm{mg}, 1.41 \mathrm{mmol})$ in THF (14. $\mathrm{mL})$ was added TBAF $(1.0 \mathrm{~mol} / \mathrm{L}$ solution in THF, $1.41 \mathrm{~mL}, 1.41 \mathrm{mmol})$ at $0{ }^{\circ} \mathrm{C}$. The reaction mixture was stirred for $17 \mathrm{~h}$ at room temperature. The mixture was extracted with ether. The organic layer was successively washed with water and brine, dried over $\mathrm{MgSO}_{4}$, and concentrated. The crude product was purified by silica gel column chromatography (hexane:AcOEt $=5: 1)$ to give $8(394 \mathrm{mg}, 94 \%)$ as a pale yellow oil. The spectral data of 8 were identical with those of the reported values. ${ }^{12}$

4.1.6. (E)-11-Iodoundec-10-enal (9). To a solution of $8(395 \mathrm{mg}, 1.33 \mathrm{mmol})$ in $\mathrm{CH}_{2} \mathrm{Cl}_{2}(1.6 \mathrm{~mL})$ and DMSO $(0.9 \mathrm{~mL})$ were added $\mathrm{Et}_{3} \mathrm{~N}(0.9 \mathrm{~mL}, 6.65 \mathrm{mmol})$ and sulfer trioxide pyridine complex $(423 \mathrm{mg}, 2.66 \mathrm{mmol})$. After stirring for $1.5 \mathrm{~h}$, the reaction was quenched with water and the organic materials were extracted with ethyl acetate. The organic layer was washed with saturated aqueous $\mathrm{NH}_{4} \mathrm{Cl}$, brine, dried over $\mathrm{MgSO}_{4}$, and concentrated. The crude product was purified by silica gel column chromatography (hexane:EtOAc $=20: 1)$ to give 9 (330 mg, $84 \%)$ as a pale yellow oil. This compound was immediately used for the next step. ${ }^{1} \mathrm{H}-\mathrm{NMR}\left(\mathrm{CDCl}_{3}\right) \delta: 1.25-1.40$ $(10 \mathrm{H}, \mathrm{m}), 1.62(2 \mathrm{H}, \mathrm{m}), 2.05(2 \mathrm{H}, \mathrm{td}, J=7.0,1.0 \mathrm{~Hz}), 2.42(2 \mathrm{H}, \mathrm{t}, J=7.0 \mathrm{~Hz}), 5.97(1 \mathrm{H}, \mathrm{dd}, J=15.0,1.0 \mathrm{~Hz})$, $6.50(1 \mathrm{H}, \mathrm{dt}, J=15.0,7.0 \mathrm{~Hz}), 9.76(1 \mathrm{H}, \mathrm{s})$.

4.1.7. (3E,13E)-14-Iodotetradeca-1,3,13-triene (10). To a solution of diethyl allylphosphonoacetate $(0.23 \mathrm{~mL}$, $1.34 \mathrm{mmol})$ in THF $(22 \mathrm{~mL})$ at $-78^{\circ} \mathrm{C}$ was added $n$-BuLi (1.6 mol/L solution in hexane, $\left.0.83 \mathrm{~mL}, 1.34 \mathrm{mmol}\right)$. After stirring for $15 \mathrm{~min}$ at this temperature, $9(330 \mathrm{mg}, 1.12 \mathrm{mmol})$ in THF-HMPA $(1: 1,4 \mathrm{~mL})$ was added dropwise. The mixture was stirred for $1.5 \mathrm{~h}$ at $-70{ }^{\circ} \mathrm{C}$. After the reaction had been completed, the mixture was extracted with ether. The organic layer was washed with saturated aqueous $\mathrm{NH}_{4} \mathrm{Cl}$, brine, dried over $\mathrm{MgSO}_{4}$, and concentrated. The crude product was purified by silica gel column chromatography (hexane) to give $\mathbf{1 0}$ (163 mg, $46 \%$ ) as a pale yellow oil. IR (film) $v_{\max } \mathrm{cm}^{-1}: 3006,2925,2852,1652,1604,1457,1436,1002,947,897 .{ }^{1} \mathrm{H}-$ NMR $\left(\mathrm{CDCl}_{3}\right) \delta: 1.25-1.40(12 \mathrm{H}, \mathrm{m}), 2.00-2.10(4 \mathrm{H}, \mathrm{m}), 4.95(1 \mathrm{H}, \mathrm{d}, J=10.5 \mathrm{~Hz}), 5.08(1 \mathrm{H}, \mathrm{d}, J=15.5 \mathrm{~Hz})$, $5.70(1 \mathrm{H}, \mathrm{dt}, J=15.0,7.0 \mathrm{~Hz}), 5.97(1 \mathrm{H}, \mathrm{d}, J=14.0 \mathrm{~Hz}), 6.05(1 \mathrm{H}, \mathrm{dd}, J=15.5 \mathrm{~Hz}, 7.0 \mathrm{~Hz}), 6.31(1 \mathrm{H}, \mathrm{dt}, J=$ 17.0, 10.5 Hz), $6.50(1 \mathrm{H}, \mathrm{dt}, J=14.0,7.0 \mathrm{~Hz}) ;{ }^{13} \mathrm{C}-\mathrm{NMR}\left(\mathrm{CDCl}_{3}\right)$ 8: 28.33, 28.89, 29.14, 29.27, 29.35, 32.53, 36.04, 74.29, 114.61, 130.85, 135.57, 137.34, 146.79. HREIMS: calcd. for $\mathrm{C}_{14} \mathrm{H}_{23} \mathrm{I}, 318.0845$; found, 318.0850 .

4.1.8. (2R,5E,17E)-Octadeca-5,15,17-trien-3-yn-2-ol (11). To a solution of 10 (130 $\mathrm{mg}, 0.41 \mathrm{mmol})$ in pyrrolidine (1.2 mL) were added $(R)$-3-butyn-1-ol (0.03 mL, $0.41 \mathrm{mmol}), \mathrm{Cl}_{2} \mathrm{Pd}\left(\mathrm{PPh}_{3}\right)_{2}(13 \mathrm{mg}, 0.018 \mathrm{mmol})$, and $\mathrm{CuI}(7 \mathrm{mg}, 0.037 \mathrm{mmol})$ and the resultant mixture was stirred for $15 \mathrm{~h}$. After the reaction had been completed, the mixture was extracted with ether. The organic layer was washed with saturated aqueous $\mathrm{NH}_{4} \mathrm{Cl}$, brine, dried 
over $\mathrm{MgSO}_{4}$, and concentrated. The crude product was purified by silica gel column chromatography (hexane:AcOEt $=5: 1)$ to give $11(77 \mathrm{mg}, 79 \%)$ as a pale yellow oil. $\left[\alpha{ }^{19} \mathrm{D}+15.9\left(\right.\right.$ c $\left.1.23, \mathrm{CHCl}_{3}\right)$, IR (film) $v_{\max } \mathrm{cm}^{-1}: 3322,2925,2853,1653,1456,1172,1078,1003,954,896 .{ }^{1} \mathrm{H}-\mathrm{NMR}\left(\mathrm{CDCl}_{3}\right)$ 8:1.25-1.60 (12H, m), $1.46(3 \mathrm{H}, \mathrm{d}, J=6.5 \mathrm{~Hz}), 1.79(1 \mathrm{H}, \mathrm{brs},-\mathrm{OH}), 2.05-2.12(4 \mathrm{H}, \mathrm{m}), 4.63(1 \mathrm{H}, \mathrm{m}), 4.95(1 \mathrm{H}, \mathrm{d}, J=10.5 \mathrm{~Hz}), 5.08$ $(1 \mathrm{H}, \mathrm{d}, J=16.0 \mathrm{~Hz}), 5.49(1 \mathrm{H}, \mathrm{dd}, J=16.0,1.8 \mathrm{~Hz}), 5.72(1 \mathrm{H}, \mathrm{dt}, J=15.0,7.0 \mathrm{~Hz}), 6.03(1 \mathrm{H}, \mathrm{dd}, J=15.0,10.5$ $\mathrm{Hz}), 6.14(1 \mathrm{H}, \mathrm{dt}, J=16.0,7.0 \mathrm{~Hz}), 6.31(1 \mathrm{H}, \mathrm{dt}, J=17.0,10.5 \mathrm{~Hz}) .{ }^{13} \mathrm{C}-\mathrm{NMR}\left(\mathrm{CDCl}_{3}\right) \delta: 24.41,28.63,29.04$, $29.14,29.33,29.37,32.52,33.04,58.84,82.86,89.32,108.72,114.60,130.84,135.59,137.34,145.55$. HREIMS: calcd. for $\mathrm{C}_{18} \mathrm{H}_{28} \mathrm{O}, 260.2140$; found, 260.2143 .

4.1.9. (2R,3Z,5E,15E)-4-Iodooctadeca-3,5,15,17-tetraen-2-ol (12). To a solution of 11 (117 mg, $0.45 \mathrm{mmol})$ in THF (1.5 mL) was added sodium bis(2-methoxyethoxy) aluminum hydride $(0.2 \mathrm{~mL}, 65 \%$ in toluene, $0.7 \mathrm{mmol})$ was added at $0{ }^{\circ} \mathrm{C}$. The reaction mixture was stirred for $1 \mathrm{~h}$ at $\mathrm{rt}$, before ethyl acetate $(0.13 \mathrm{~mL}, 1.4 \mathrm{mmol})$ was added. After the mixture had been cooled at $-78{ }^{\circ} \mathrm{C}$, a solution of iodine ( $\left.345 \mathrm{mg}, 1.4 \mathrm{mmol}\right)$ in THF (2 ml) was added dropwise. The reaction mixture was allowed to warm to room temperature, the reaction was quenched with a saturated aqueous $\mathrm{Na}_{2} \mathrm{~S}_{2} \mathrm{O}_{3}$. The mixture was extracted with ether. The organic layer was successively washed with saturated aqueous $\mathrm{NaHCO}_{3}$ and brine, dried over $\mathrm{MgSO}_{4}$, and concentrated. The crude product was purified by preparative TLC (hexane:AcOEt $=5: 1)$ to give $12(131 \mathrm{mg}, 75 \%)$ as a pale yellow oil. $[\alpha]^{19}+8.60(c$ 1.69, $\mathrm{CHCl}_{3}$ ), IR (film) $v_{\max } \mathrm{cm}^{-1}: 3331,2971,2925,2852,1651,1602,1125,1058,1002,948,896 .{ }^{1} \mathrm{H}-\mathrm{NMR}$ $\left(\mathrm{CDCl}_{3}\right) \delta: 1.20-1.45(12 \mathrm{H}, \mathrm{m}), 1.38(3 \mathrm{H}, \mathrm{d}, J=7.5 \mathrm{~Hz}), 1.92(1 \mathrm{H}, \mathrm{brs}), 2.05-2.10(2 \mathrm{H}, \mathrm{m}), 2.16-2.22(2 \mathrm{H}, \mathrm{m})$, 4.67-4.70 (1H, m), $4.95(1 \mathrm{H}, \mathrm{d}, J=10.5 \mathrm{~Hz}), 5.08(1 \mathrm{H}, \mathrm{d}, J=17.0 \mathrm{~Hz}), 5.67-5.73(2 \mathrm{H}, \mathrm{m}), 5.83(1 \mathrm{H}, \mathrm{d}, J=7.5$ $\mathrm{Hz}), 5.99-6.07(2 \mathrm{H}, \mathrm{m}), 6.31(1 \mathrm{H}, \mathrm{dt}, J=17.0,7.0 \mathrm{~Hz}) .{ }^{13} \mathrm{C}-\mathrm{NMR}\left(\mathrm{CDCl}_{3}\right) \delta: 22.00,29.13,29.16,29.38,31.93$, 32.52, 72.37, 105.95, 114.58, 130.82, 131.10, 135.57, 137.32, 140.23, 140.53. HREIMS: calcd. for $\mathrm{C}_{18} \mathrm{H}_{29} \mathrm{IO}$, 388.1263; found, 388.1265 .

4.1.10. (R)-(-)-Akolactone B (1a). To a solution of $12(50 \mathrm{mg}, 0.13 \mathrm{mmol})$ in THF were added $\mathrm{K}_{2} \mathrm{CO}_{3}(36 \mathrm{mg}$, $0.26 \mathrm{mmol}), \mathrm{NH}_{2} \mathrm{NH}_{2}(10 \mathrm{mg})$, and $\mathrm{Et}_{3} \mathrm{~N}(0.02 \mathrm{~mL}, 0.13 \mathrm{mmol})$ under $\mathrm{CO}$ atmosphere. The mixture was stirred for $16 \mathrm{~h}$ at $40{ }^{\circ} \mathrm{C}$. After cooling, the mixture was filtered through Celite and the solvent was concentrated. The residue was purified with preparative TLC (hexane:AcOEt $=5: 1)$ to afford $1 \mathbf{a}(23 \mathrm{mg}, 63 \%)$ as a pale yellow oil. $[\alpha]^{18} \mathrm{D}-38.1\left(c 1.10, \mathrm{CHCl}_{3}\right)$, \{natural akolactone $\left.\mathrm{B},[\alpha]^{27} \mathrm{D}=-10.0,\left(c 0.10, \mathrm{CHCl}_{3}\right)\right\}{ }^{2 \mathrm{a}} \mathrm{IR}($ film $) v_{\max } \mathrm{cm}^{-1}: 3030$, 2925, 2853, 1755, 1318, 1082, 1003. ${ }^{1} \mathrm{H}-\mathrm{NMR}\left(\mathrm{CDCl}_{3}\right) \delta: 1.20-1.50(12 \mathrm{H}, \mathrm{m}), 1.43(3 \mathrm{H}, \mathrm{d}, J=6.5 \mathrm{~Hz}), 2.05-$ $2.08(2 \mathrm{H}, \mathrm{m}), 2.13-2.18(2 \mathrm{H}, \mathrm{m}), 4.95(1 \mathrm{H}, \mathrm{d}, J=10.0 \mathrm{~Hz}), 5.02(1 \mathrm{H}, \mathrm{qd}, J=6.5,1.5 \mathrm{~Hz}), 5.08(1 \mathrm{H}, \mathrm{d}, J=17.0$ $\mathrm{Hz}), 5.71(1 \mathrm{H}, \mathrm{dt}, J=15.0,7.5 \mathrm{~Hz}), 6.00-6.05(1 \mathrm{H}, \mathrm{m}), 6.09(1 \mathrm{H}, \mathrm{d}, J=16.0 \mathrm{~Hz}), 6.31(1 \mathrm{H}, \mathrm{dt}, J=17.0,10.0 \mathrm{~Hz})$, $6.79(1 \mathrm{H}, \mathrm{dt}, J=16.0,7.0 \mathrm{~Hz}), 7.03(1 \mathrm{H}, \mathrm{d}, J=1.5 \mathrm{~Hz}) .{ }^{13} \mathrm{C}-\mathrm{NMR}\left(\mathrm{CDCl}_{3}\right) \delta: 19.18,28.74,29.14,29.16,29.20$, $29.38(2 \times \mathrm{C}), 32.53,33.41,76.91,114.58,118.28,129.41,130.82,135.62,137.35,138.84,146.83,172.06$. HREIMS: calcd. for $\mathrm{C}_{19} \mathrm{H}_{28} \mathrm{O}_{2}, 288.2089$; found, 288.2086. 
4.1.11. (S)-(+)-Akolactone B (1b). $[\alpha]^{19} \mathrm{D}+35.8\left(c \quad 0.500, \mathrm{CHCl}_{3}\right)$. The ${ }^{1} \mathrm{H}$ - and ${ }^{13} \mathrm{C}-\mathrm{NMR}$, and IR spectra were identical with those of 1a. HREIMS: calcd. for $\mathrm{C}_{19} \mathrm{H}_{28} \mathrm{O}_{2}, 288.2089$; found, 288.2091.

4.1.12. 1,12-Diiodododecane (14). To a solution of 1,12-dodecanediol (1.06 g, $5.23 \mathrm{mmol})$ and $\mathrm{Et}_{3} \mathrm{~N}(2.9 \mathrm{~mL}$, $20.9 \mathrm{mmol})$ in $\mathrm{CH}_{2} \mathrm{Cl}_{2}(17 \mathrm{~mL})$ was $\mathrm{MsCl}(1.01 \mathrm{~mL}, 13.1 \mathrm{mmol})$ at $0^{\circ} \mathrm{C}$. The reaction mixture was stirred for $5 \mathrm{~h}$ at $0^{\circ} \mathrm{C}$. After the reaction had been completed, the mixture was extracted with ether. The organic layer was successively washed with saturated aqueous $\mathrm{NH}_{4} \mathrm{Cl}$, water, and brine, dried over $\mathrm{MgSO}_{4}$, and concentrated. The crude product was dissolved in acetone $(20 \mathrm{~mL})$ and $\mathrm{NaI}(3.90 \mathrm{~g}, 26 \mathrm{mmol})$ was added to this solution. After being stirred for $16 \mathrm{~h}$, the reaction was quenched with water. The organic materials were extracted with ether and organic layer was successively washed with water and brine, dried over $\mathrm{MgSO}_{4}$, and concentrated. The crude product was purified by silica gel column chromatography (hexane:AcOEt $=20: 1)$ to give $14(1.85 \mathrm{~g}, 84 \%)$ as a colorless solid. The ${ }^{1} \mathrm{H}$ NMR spectral data of $\mathbf{1 4}$ were identical with those of reported value. ${ }^{15}$

4.1.13. (2S,19S)-2,19-bis-(tert-Butyldimethylsilyoxy)eicosa-3,17-diyne (15). To a solution of (S)-3-(tertbutyldimethylsilyloxy)but-1-yne $(923 \mathrm{mg}, 5.0 \mathrm{mmol})$ in THF $(7.4 \mathrm{~mL})$ was added $n$-BuLi $(1.6 \mathrm{~mol} / \mathrm{L}$ solution in hexane, $4.0 \mathrm{~mL}, 6.54 \mathrm{mmol})$ at $-78{ }^{\circ} \mathrm{C}$. After being stirred for $1.5 \mathrm{~h}$ at $0{ }^{\circ} \mathrm{C}, 14(920 \mathrm{mg}, 2.18 \mathrm{mmol})$ in HMPA $(1.5 \mathrm{~mL})$ and THF $(2.0 \mathrm{~mL})$ was added. The reaction mixture was allowed to warm to room temperature, the reaction was quenched with saturated aqueous $\mathrm{NH}_{4} \mathrm{Cl}$, and the mixture was extracted with ether. The organic layer was washed with brine, dried over $\mathrm{MgSO}_{4}$, and concentrated. The crude product was purified by silica gel column chromatography (hexane:AcOEt $=20: 1)$ to give $15(1.10 \mathrm{~g}, 94 \%)$ as a pale yellow oil. $[\alpha]^{18}-5.41(c$ 1.44, $\left.\mathrm{CHCl}_{3}\right)$, IR (film) $v_{\max } \mathrm{cm}^{-1}: 2928,2856,1463,1252,1101,1087,833,777 .{ }^{1} \mathrm{H}-\mathrm{NMR}\left(\mathrm{CDCl}_{3}\right) \delta: 0.11(6 \mathrm{H}$, s), $0.12(6 \mathrm{H}, \mathrm{s}), 0.90(18 \mathrm{H}, \mathrm{s}), 1.20-1.27(16 \mathrm{H}, \mathrm{m}), 1.38(6 \mathrm{H}, \mathrm{d}, J=6.5 \mathrm{~Hz}), 1.46-1.50(4 \mathrm{H}, \mathrm{m}), 2.17(4 \mathrm{H}, \mathrm{dt}, J=$ 7.0, $2.0 \mathrm{~Hz}), 4.50(2 \mathrm{H}, \mathrm{qd}, J=6.5,2.0 \mathrm{~Hz}) .{ }^{13} \mathrm{C}-\mathrm{NMR}\left(\mathrm{CDCl}_{3}\right) \delta:-4.91,-4.59,18.29,18.65,25.84,28.64,28.84$, 29.14, 29.54, 29.60, 53.41, 59.22, 82.72, 83.72. HREIMS: calcd. for $\mathrm{C}_{32} \mathrm{H}_{62} \mathrm{O}_{2} \mathrm{Si}_{2}$, 534.4288; found, 534.4293.

4.1.14. (2S,19S)-Eicosa-3,17-diyne-2,19-diol (16). To a solution of 15 (967 mg, $1.8 \mathrm{mmol})$ in THF (5.5. mL) was added TBAF $(1.0 \mathrm{~mol} / \mathrm{L}$ solution in THF, $3.6 \mathrm{~mL}, 3.6 \mathrm{mmol})$ at $0{ }^{\circ} \mathrm{C}$. The reaction mixture was stirred for 14 $\mathrm{h}$ at room temperature. The mixture was extracted with ether. The organic layer was successively washed with water and brine, dried over $\mathrm{MgSO}_{4}$, and concentrated. The crude product was purified by silica gel column chromatography (hexane:AcOEt $=2: 1)$ to give $16(337 \mathrm{mg}, 61 \%)$ as a colorless solid. Mp. $58-59^{\circ} \mathrm{C},[\alpha]^{21} \mathrm{D}-26.2$ (c $\left.0.635, \mathrm{CHCl}_{3}\right)$, IR (KBr) $v_{\max } \mathrm{cm}^{-1}: 3324,2980,2918,2848,1470,1149,1075,891 .{ }^{1} \mathrm{H}-\mathrm{NMR}\left(\mathrm{CDCl}_{3}\right) \delta: 1.20$ $1.50(20 \mathrm{H}, \mathrm{m}), 1.43(6 \mathrm{H}, \mathrm{d}, J=6.5 \mathrm{~Hz}), 1.79(2 \mathrm{H}, \mathrm{brs}), 2.46(4 \mathrm{H}, \mathrm{dt}, J=7.0,2.0 \mathrm{~Hz}), 4.47$ (2H, q, $J=6.5 \mathrm{~Hz})$. ${ }^{13} \mathrm{C}-\mathrm{NMR}\left(\mathrm{CDCl}_{3}\right) \delta: 18.59,24.72,28.58,28.79,29.06,29.44,29.52,58.56,82.16,84.71$. HREIMS: calcd. for $\mathrm{C}_{20} \mathrm{H}_{34} \mathrm{O}_{2}, 306.2559$; found, 306.2561 . 
4.1.15. (2S,19S)-4,17-Diiodoeicosa-3,17-diene-2,19-diol (17). To a solution of 16 (149 mg, $0.49 \mathrm{mmol})$ in THF $(10 \mathrm{~mL})$ was added sodium bis(2-methoxyethoxy) aluminum hydride $(0.8 \mathrm{~mL}, 65 \%$ in toluene, $4.1 \mathrm{mmol})$ was added at $0{ }^{\circ} \mathrm{C}$. The reaction mixture was stirred for $3 \mathrm{~h}$ at $\mathrm{rt}$, before ethyl acetate $(0.4 \mathrm{~mL}, 3.9 \mathrm{mmol})$ was added at $0{ }^{\circ} \mathrm{C}$. After the mixture had been cooled at $-78^{\circ} \mathrm{C}$, a solution of iodine $(1.11 \mathrm{~g}, 4.4 \mathrm{mmol})$ in THF $(7 \mathrm{ml})$ was added dropwise. The reaction mixture was allowed to warm to $\mathrm{rt}$, the reaction was quenched with saturated aqueous $\mathrm{Na}_{2} \mathrm{~S}_{2} \mathrm{O}_{3}$. The mixture was extracted with ether. The organic layer was successively washed with saturated aqueous $\mathrm{NaHCO}_{3}$ and brine, dried over $\mathrm{MgSO}_{4}$, and concentrated. The crude product was purified by preparative TLC (hexane:AcOEt $=5: 1)$ to give $17(234 \mathrm{mg}, 86 \%)$ as a pale yellow oil. $[\alpha]^{18}{ }_{\mathrm{D}}-0.030(c 1.25$, $\mathrm{CHCl}_{3}$ ), IR (film) $v_{\max } \mathrm{cm}^{-1}: 3326,2970,2925,2852,1644,1366,1247,1114,1065,941,867 .{ }^{1} \mathrm{H}-\mathrm{NMR}\left(\mathrm{CDCl}_{3}\right)$ $\delta: 1.20-1.35(16 \mathrm{H}, \mathrm{m}), 1.31(6 \mathrm{H}, \mathrm{d}, J=6.5 \mathrm{~Hz}), 1.45-1.50(4 \mathrm{H}, \mathrm{m}), 1.79(2 \mathrm{H}, \mathrm{brs}), 2.46(4 \mathrm{H}, \mathrm{dt}, J=1.0,7.0 \mathrm{~Hz})$, $4.47(2 \mathrm{H}, \mathrm{m}), 5.60(2 \mathrm{H}, \mathrm{d}, J=7.0 \mathrm{~Hz}) .{ }^{13} \mathrm{C}-\mathrm{NMR}\left(\mathrm{CDCl}_{3}\right) \delta: 22.01,28.12,29.07,29.28,29.46,29.53,45.12$, 72.83, 109.50, 137.97. HREIMS: calcd. for $\mathrm{C}_{20} \mathrm{H}_{36} \mathrm{I}_{2} \mathrm{O}_{2}, 562.0805$; found, 562.0803 .

4.1.15. (+)-Ancepsenolide (2). To a solution of 17 (30 mg, $0.053 \mathrm{mmol})$ in THF were added $\mathrm{K}_{2} \mathrm{CO}_{3}(30 \mathrm{mg}, 0.21$ $\mathrm{mmol}$ ), $\mathrm{NH}_{2} \mathrm{NH}_{2}$ (one drop), and $\mathrm{Et}_{3} \mathrm{~N}(0.03 \mathrm{~mL}, 0.21 \mathrm{mmol})$ under $\mathrm{CO}$ atmosphere. The mixture was stirred for $44 \mathrm{~h}$ at $40{ }^{\circ} \mathrm{C}$. After cooling, the mixture was diluted with EtOAc, washed with satrated aqueous $\mathrm{NH}_{4} \mathrm{Cl}$, brine, dried over $\mathrm{MgSO}_{4}$, and concentrated. The residue was purified with preparative TLC (toluene:AcOEt $\left.=4: 1\right)$ to afford 3 (15 mg, 79\%) with monolactonized product. Mp. 96-97 ${ }^{\circ} \mathrm{C}$, (lit., 96.0-97.9 $\left.{ }^{\circ} \mathrm{C}\right){ }^{4}[\alpha]^{18} \mathrm{D}+47.1(c 1.28$, $\left.\mathrm{CHCl}_{3}\right),\left\{\right.$ lit., $\left.[\alpha]^{27} \mathrm{D}=+45.53,\left(c \mathrm{0.43}, \mathrm{CHCl}_{3}\right)\right\} .{ }^{6 \mathrm{a}} \mathrm{IR}(\mathrm{KBr}) v_{\max } \mathrm{cm}^{-1}: 3076,2913,2849,1743,1652,1472,1326$, 1205, 1121, 1085, 1035, 884. ${ }^{1} \mathrm{H}-\mathrm{NMR}\left(\mathrm{CDCl}_{3}\right) \delta: 1.20-1.60(20 \mathrm{H}, \mathrm{m}), 1.41(6 \mathrm{H}, \mathrm{d}, J=7.0 \mathrm{~Hz}), 2.25-2.28(4 \mathrm{H}$, m), $5.00(2 \mathrm{H}, \mathrm{qd}, J=7.0,1.5 \mathrm{~Hz}), 6.99(2 \mathrm{H}, \mathrm{d}, J=1.5 \mathrm{~Hz}) .{ }^{13} \mathrm{C}-\mathrm{NMR}\left(\mathrm{CDCl}_{3}\right) \delta: 19.20,25.15,27.37,29.15$, 29.27, 29.46, 29.53, 77.40, 134.28, 148.87, 173.91. HREIMS: calcd. for $\mathrm{C}_{22} \mathrm{H}_{34} \mathrm{O}_{4}, 362.2457$; found, 362.2455 .

\section{Acknowledgements}

This work was supported in part by JSPS KAKENHI Grant Number 24580160 to H. M.

\section{References}

1. (a) Makabe, H.; Konno, H.; Miyoshi, H. Curr. Drug Discovery Technol. 2008, 5, 213; (b) McLaughlin, J. L. J. Nat. Prod. 2008, 71, 1311. (c) Hattori, Y.; Konno, H.; Miyoshi, H.; Makabe, H. J. Synth. Org. Chem. Jpn. 2011, 69, 159. (d) Makabe, H. Biosci. Biotechnol. Biochem. 2007, 71, 2367. (d) Bermejo, A.; Figadère, B.; Zafra-Polo, M.-C.; Barrachina, I.; Estoneroll, E.; Cortes, D. Nat. Prod. Rep. 2005, 22, 269.

2. (a) Chen, I. -S.; Lai-Yaun, I. -L.; Duh, C. -Y.; Tsai, I. -L. Phytochemistry 1998, 49, 745; (b) Min, B. S.; Lee, S. Y.; Kim, J. H.; Kwon, O. K.: Park, B. Y.; An, R. B.; Lee, J. K.; Moon, H. I.; Kim, T. J.; Kim, Y. H.; Joung, H.; Lee, H. K. J. Nat. Prod. 2003, 66, 1388.

3. (a) Ciereszko, L. S.; Siffod, D. H.; Weinheimer, A. J. Ann. N. Y. Acad. Sci. 1960, 90, 917; (b) Schmitz, F. J.; 
Kraus, K. W.; Ciereszko, L. S.; Sifford, D. H.; Weinheimer, A. J. Tetrahedron Lett. 1966, 7, 97.

4. Rodoríguez, A. D.; Ramírez, C. J. Nat. Prod. 1994, 57, 339.

5. Schmitz, F. J.; Lorance, E. D. J. Org. Chem. 1971, 36, 719.

6. (a) Ghobril, C.; Kister, J.; Baati, R. Eur. J. Org. Chem. 2011, 3416; (b) Takai, K.; Iriye, R. Biosci. Biotechnol. Biochem. 2001, 65, 1903; (c) Trost, B. M.; Müller, T. J. J.; Martinetz, J. J. Am. Chem. Soc. 1994, 116, 4985.

7. Makabe, H.; Okajima, M.; Konno, H.; Kamo, T.; Hirota, M. Biosci. Biotechnol. Biochem. 2003, 67, 2658.

8. Iwashita, H.; Sone, H.; Kigoshi, H.; Yamada, K. Tetrahedron 1994, 50, 12853.

9. Kalivretenos, A.; Stille, J. K.; Hegedus, L. S. J. Org. Chem. 1991, 56, 2883.

10. Liang, G. J.; Zhang, J. Z.; Chen, A. Q. Chin. Chem. Lett. 2005, 16, 601.

11. Hart, D. W.; Schwarz, J. J. Am. Chem. Soc. 1974, 96, 8115.

12. Miyaura, N.; Suginome, H.; Suzuki, A. Tetrahedron 1983, 39, 3271.

13. Alami, M.; Ferri, F.; Linstrumelle, G. Tetrahedron Lett. 1993, 34, 6403.

14. Hoye, T. R.; Zhixiong, Y. J. Am. Chem. Soc. 1996, 118, 1801.

15. Ainscow, T. A.; Belmont, M. R.; Henshall, J. L.; Hooper, R. M.; Simmonds, D. J. Tetrahedron 1987, 43, 115. 